\title{
The effect of feeding low-phytate hulless barley- soyabean meal diets differing in protein content to growing pigs on phosphorus and nitrogen excretion
}

\author{
J.K. Htoo ${ }^{1}$, W.C. Sauer ${ }^{1,2,3}$, B.A. Araiza ${ }^{2}$, M. Cervantes ${ }^{2}$, S.F. Liao ${ }^{1}$ and \\ Y. Zhang ${ }^{1}$ \\ ${ }^{1}$ Department of Agricultural, Food and Nutritional Science, University of Alberta \\ Edmonton, Alberta T6G 2P5, Canada \\ ${ }^{2}$ Instituto de Ciencias Agrícolas, Universidad Autónoma de Baja California \\ Mexicali, México 21100
}

(Received 31 July 2006; accepted 2 February 2007)

\begin{abstract}
An experiment was conducted with growing pigs to determine the excretion of $\mathrm{P}$ and $\mathrm{N}$ in 4 barley-based diets formulated to contain 18 or $15 \% \mathrm{CP}$ by using a normal hulless barley $(\mathrm{HB})$ or a low-phytate hulless barley (LPHB). The HB contained $0.27 \%$ total P and $0.14 \%$ phytate P; the LPHB contained $0.24 \%$ total $\mathrm{P}$ and $0.03 \%$ phytate $\mathrm{P}$. The diets were supplemented with lysine, methionine, threonine, and tryptophan to meet their apparent ileal digestible supplies according to the National Research Council (NRC). All diets were supplemented with inorganic P to meet the NRC recommendation for available P (0.23\%). Eight barrows, average body weight $20.4 \mathrm{~kg}$, were assigned to the 4 dietary treatments according to a repeated $4 \times 4$ Latin square design. The diets were fed at a rate of 2.5 the ME requirement for maintenance. The barrows were fed twice daily, at 8 a.m. and 4 p.m., equal amounts each meal. Water was added to the feed at a ratio of 2.5 to 1 . Each experimental period consisted of a 7-d adaptation period followed by a 5-d collection of faeces and urine. The substitution of HB with LPHB decreased $(\mathrm{P}<0.001)$ the total $\mathrm{P}$ excretion by 33.5 and $35 \%$ for the 18 and $15 \%$ CP diets, respectively. Reducing the CP content from 18 to $15 \%$ decreased $(\mathrm{P}<0.001)$ the $\mathrm{N}$ excretion by $26 \%$ for both the HB and LPHB diets. With the reduction in $\mathrm{CP}$ content, there was a decrease $(\mathrm{P}<0.001)$ in the amount of $\mathrm{N}$ retained. The $\mathrm{N}: \mathrm{P}$ ratio in excreta of pigs fed the LPHB diets was higher $(\mathrm{P}<0.001)$ than of pigs fed the HB diets. The digestibility of $\mathrm{N}$ was higher $(\mathrm{P}<0.001)$ in pigs fed the LPHB compared to the HB diets. The data indicate that $\mathrm{P}$ and $\mathrm{N}$ excretions can be greatly reduced by substitution of HB by LPHB, and by the reduction of the CP content, respectively in diets for growing pigs.
\end{abstract}

KEY WORDS: pigs, phosphorus, nitrogen, balance, low-phytate barley

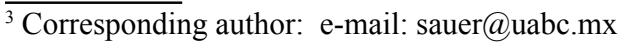




\section{INTRODUCTION}

Barley is a commonly used feed ingredient in diets for growing and finishing pigs in western-Canada and many countries. It ranks fourth after wheat, rice and maize in world cereal production (FAO, 2002).

Approximately two thirds of phosphorus $(\mathrm{P})$ in commonly used feed ingredients of plant origin, including barley, is present in the form of phytate (Ravindran et al., 1995). Phytate $\mathrm{P}$ is poorly utilized by monogastric animals such as pigs due to insufficient activity of endogenous phytases (Nelson, 1967). Most of the phytate $\mathrm{P}$ is excreted and can lead to environmental pollution. Inorganic $\mathrm{P}$ sources are routinely added to the diet to meet the $\mathrm{P}$ requirements. Phosphorus from animal manure is becoming an increasing environmental concern in many countries (Jongbloed and Lenis, 1998). Therefore, there is more and more interest in nutritional strategies to minimize $\mathrm{P}$ excretion in manure.

There are also concerns about environmental pollution resulting from nitrogen (N) excretion (Otto et al., 2003). Reducing the dietary crude protein (CP) content by 3 to 4 percentage units with appropriate AA supplementation decreased $\mathrm{N}$ excretion by 24 to $40 \%$ (Sutton et al., 1999; Schriver et al., 2003).

One method to reduce P excretion, besides the use of phytase, is the use of lowphytate crops in pig diets. In recent years, low-phytate crops have been developed, including low-phytate hulless barleys (LPHB) that are phenotypically identical to normal hulless barleys (HB). There is little difference in the total P contents between HB and LPHB. There is also more and more interest in the cultivation of HB in western-Canada, as the digestible energy content in HB fed to pigs is approximately 8 to $10 \%$ higher than in hulled barley (Huang et al., 2003).

The first objective of this study was to determine the apparent total tract digestibility (ATTD), retention and excretion of $\mathrm{P}$ and $\mathrm{N}$ in growing pigs fed LPHB-soyabean meal (SBM) diets compared to those fed HB-SBM diets. The second objective was to determine to which extent $\mathrm{N}$ excretion can be reduced upon a 3 percentage units decrease in the dietary CP content of the HB- and LPHB-SBM diets.

\section{MATERIAL AND METHODS}

\section{Animals and dietary treatments}

Nine crossbred barrows (Large WhitexLandrace), average initial body weight (BW) $19.9 \pm 1.1 \mathrm{~kg}$, were obtained from the Swine Research Unit of the University of Alberta and housed individually in stainless steel metabolic crates (height $=82 \mathrm{~cm}$; 
length $=124 \mathrm{~cm}$; width $=76 \mathrm{~cm})$ in a temperature-controlled room $\left(22 \pm 1^{\circ} \mathrm{C}\right)$. During a 7-d adaptation period to the crates, the barrows were fed ad libitum an $18 \% \mathrm{CP}$ grower diet. Water was freely available from a low-pressure drinking nipple.

Based on feed intake, eights barrows were selected and fed four diets according to a repeated $4 \times 4$ Latin square design. Each of the four experimental periods comprised $13 \mathrm{~d}$. The barrows were fed twice daily, equal amounts each meal, at 8 a.m. and 4 p.m. The diets were fed at a rate of 2.5 times the maintenance requirement for metabolizable energy (ME) (i.e. $444 \mathrm{~kJ} \mathrm{BW}_{\mathrm{kg}}^{0.75}$ ) based on the average $\mathrm{BW}$ of the pigs, which was recorded at the initiation of each experimental period. The formulation of the experimental diets was as follows (Table 1). Diet 1: hulless barley (c.v. Falcon)-SBM, 18\% CP; Diet 2: hulless barley (c.v. Falcon)SBM, 15\% CP; Diet 3: low-phytate hulless barley (mutant line 99054)-SBM, 18\% CP; Diet 4: low-phytate hulless barley (mutant line 99054)-SBM, 15\% CP. The hulless barleys used in this experiment were supplied by Dr. J. Helm (Field Crop Development Centre, 5030 - 50 Street, Lacombe, AB T4L 1W8, Canada).

Table 1. Composition of the experimental diets, $\%$ as-fed basis

\begin{tabular}{|c|c|c|c|c|}
\hline \multirow{3}{*}{ Ingredients } & \multicolumn{4}{|c|}{ Diets } \\
\hline & \multicolumn{2}{|c|}{$\mathrm{HB}^{1}$} & \multicolumn{2}{|c|}{ LPHB $^{2}$} \\
\hline & $18 \% \mathrm{CP}$ & $15 \% \mathrm{CP}$ & $18 \% \mathrm{CP}$ & $15 \% \mathrm{CP}$ \\
\hline Hulless barley & 74.75 & 83.48 & - & - \\
\hline Low-phytate hulless barley & - & - & 79.40 & 88.62 \\
\hline Soyabean meal, $48 \%$ & 20.00 & 9.50 & 14.80 & 3.80 \\
\hline L-Lysine $\cdot \mathrm{HCl}$ & 0.13 & 0.45 & 0.21 & 0.54 \\
\hline DL-Methionine & 0.03 & 0.07 & 0.05 & 0.09 \\
\hline L-Threonine & 0.06 & 0.17 & 0.08 & 0.19 \\
\hline L-Tryptophan & 0.01 & 0.06 & 0.05 & 0.09 \\
\hline Canola oil & 2.60 & 3.72 & 3.06 & 4.22 \\
\hline Limestone & 1.15 & 1.25 & 1.35 & 1.45 \\
\hline Monocalcium phosphate $^{3}$ & 0.47 & 0.50 & 0.20 & 0.20 \\
\hline Iodized salt & 0.25 & 0.25 & 0.25 & 0.25 \\
\hline Mineral premix ${ }^{4}$ & 0.10 & 0.10 & 0.10 & 0.10 \\
\hline Vitamin premix ${ }^{5}$ & 0.10 & 0.10 & 0.10 & 0.10 \\
\hline Choline chloride ${ }^{6}$ & 0.05 & 0.05 & 0.05 & 0.05 \\
\hline Chromic oxide & 0.30 & 0.30 & 0.30 & 0.30 \\
\hline
\end{tabular}

${ }^{1}$ normal hulless barley (c.v. Falcon)

${ }^{2}$ low-phytate hulless barley (mutant line 99054)

${ }^{3}$ monocalcium phosphate contains $17 \% \mathrm{Ca}$ and $21.1 \% \mathrm{P}$

${ }^{4}$ supplied by Champion Feed Service Ltd., Westlock, Alberta, Canada. The mineral premix provided per kg of diet, mg: Fe 150; Zn 150; Mn 40; Cu 25; I 0.21; Co 0.5; Se 0.3; and Ethoxyquin 5.0

${ }^{5}$ supplied by Champion Feed Service Ltd. The vitamin premix provided per $\mathrm{kg}$ of diet, IU: vit. A 10,000 ; vit. $\mathrm{D}_{3} 1,000$; vit. $\mathrm{E} 80$; mg: vit. $\mathrm{K}_{3} 2.0$; vit. $\mathrm{B}_{12} 0.03$; riboflavin 12 ; niacin 40; D-pantothenic acid 25; biotin 0.25; folic acid 1.6; thiamine 3.0; and pyridoxine 2.25

${ }^{6}$ supplied by Champion Feed Service Ltd. Choline chloride provided $0.3 \mathrm{~g}$ choline chloride per $\mathrm{kg}$ of diet 
The diets were supplemented with lysine, methionine, threonine, and tryptophan to meet their apparent ileal digestible supplies according to the NRC (1998) standards. All diets were supplemented with monocalcium phosphate to meet the NRC (1998) standard for available phosphorus (aP) for pigs over the BW range of 20 to $50 \mathrm{~kg}$, which is $0.23 \%$. Canola oil was included in the diets to meet the NRC (1998) standard for ME. Vitamins and minerals were supplemented to meet or exceed the NRC (1998) standards. Chromic oxide (0.3\%) was included in the diets as an indigestible marker. The barleys were ground through a 2-mm mesh screen prior to incorporation into the diets. The diets were fed in mash form. Water was mixed with the feed at a ratio of 2.5 to $1(\mathrm{wt} / \mathrm{wt})$ and was freely available between meals.

The experimental proposal and procedures for care and treatment of the pigs were reviewed and approved by the Animal Care Committee of the University of Alberta in accordance with the guidelines of CCAC (1993).

\section{Sample collection and chemical analysis}

Samples of the major feed ingredients were taken before diet formulation. Samples of the diets were taken during the time the meal allowances were prepared. The collection of faeces was initiated at 8 a.m. on $\mathrm{d} 8$ of each experimental period and continued for 120 consecutive hours. Faeces were collected at 8 a.m. and 4 p.m. and immediately frozen at $-28^{\circ} \mathrm{C}$. Faeces contaminated with feed and urine or trampled on were discarded. A total collection of urine was carried out during the same time faeces were collected. Urine were collected into a container through glass wool, measured volumetrically and a sub-sample ( $20 \%$ of total volume) was stored at $-4^{\circ} \mathrm{C}$. Before collection, $5 \mathrm{~mL}$ of $10 \%$ ( $\mathrm{vol} / \mathrm{vol}$ ) formic acid solution was placed into each container.

Prior to chemical analyses, faeces and urine were pooled for each pig in each experimental period. Faeces were dried in a forced-draft oven at $55^{\circ} \mathrm{C}$ until constant weight. The dried samples of faeces, samples of ingredients and diets were ground through a $0.5-\mathrm{mm}$ mesh screen in a Thomas-Wiley Laboratory Mill (Arther H. Thomas Co., Philadelphia, PA, USA). Urine samples were filtered through Whatman \#2 filter paper and then dried in a forced-draft oven prior to analysis.

Analyses for dry matter (DM), organic mater (OM) and gross energy (GE) were carried out according to AOAC $(2000)$. Crude protein $(\mathrm{N} \times 6.25)$ was determined with a Leco FP-428 Nitrogen Determinator (Leco Corporation, St. Joseph, MI), gross energy with an AC-300 Leco Automatic Calorimeter and phosphorus spectrophotometrically by the molybdovanadate procedure 
(Method 965.17; AOAC, 2000). Phytate P contents in the barleys were analysed according to the procedure described by Haug and Lantzsch (1983). Chromic oxide was determined with a spectrophotometric procedure according to Fenton and Fenton (1979). Amino acid (AA) analyses of the diets were carried out at Degussa AG, Hanau-Wolfgang (Germany). The procedure for AA analysis was previously described in detail by Kaufmann et al. (2005). Analyses of diets and barleys were carried out in triplicate; analyses of faeces and urine in duplicate.

\section{Calculations and statistical analyses}

The ATTD of DM, OM, N, and P were calculated by using the following equation:

$$
\mathrm{D}_{\mathrm{D}}=100 \%-\left[\left(\mathrm{A}_{\mathrm{F}} \times \mathrm{I}_{\mathrm{D}}\right) /\left(\mathrm{A}_{\mathrm{D}} \times \mathrm{I}_{\mathrm{F}}\right)\right] \times 100 \%
$$

where $\mathrm{D}_{\mathrm{D}}$ is the ATTD of a parameter in the assay diet (\%), $\mathrm{A}_{\mathrm{F}}$ is the concentration of a parameter in faeces (\%), $\mathrm{I}_{\mathrm{D}}$ is the chromic oxide concentration in the assay $\operatorname{diet}(\%), A_{D}$ is the concentration of a parameter in the assay diet (\%), and $I_{F}$ is the chromic oxide concentration in faeces (\%).

The total $\mathrm{N}$ and $\mathrm{P}$ excretions in faeces were estimated taking into account the intake of $\mathrm{N}$ and $\mathrm{P}$, and their digestibility coefficients (determined by aid of chromic oxide).

The data were subjected to statistical analyses for a repeated $4 \times 4$ Latin square design using the GLM procedure of SAS (1988). The main effects of diets $(n=4)$, pigs $(n=8)$, and experimental periods $(n=4)$ were included in the model. Three orthogonal contrasts were constructed to test the effect of dietary $\mathrm{CP}$ content $\left(\mathrm{C}_{1}=18 \mathrm{CP}\right.$ vs $\left.15 \% \mathrm{CP}\right)$, barley type $\left(\mathrm{C}_{2}=\right.$ normal vs low-phytate barley $)$ and interaction $\left(\mathrm{C}_{3}=\mathrm{CP}\right.$ content $\times$ barley type $)$. A probability level of $\mathrm{P} \leq 0.05$ was defined as significant difference.

\section{RESULTS}

The CP contents of HB and LPHB were 11.42 and $13.82 \%$, respectively. The contents of phytate P in HB and LPHB were 0.14 and $0.03 \%$, respectively. In the same order for the barley types, the contents of $\mathrm{P}$ were 0.27 and $0.24 \%$. By difference (total P-phytate P) the aP contents in HB and LPHB were 0.13 and $0.21 \%$, respectively. The chemical composition of the diets are presented in Table 2. The apparent ileal digestible contents of lysine, methionine and cystine, threonine, and tryptophan were similar between the experimental diets. 
Table 2. Analysed chemical composition of the experimental diets, as-fed basis

\begin{tabular}{|c|c|c|c|c|}
\hline \multirow[t]{3}{*}{ Item } & \multicolumn{4}{|c|}{ Diets $^{1}$} \\
\hline & \multirow{2}{*}{$\frac{\mathrm{HB}}{18 \% \mathrm{CP}}$} & \multicolumn{3}{|c|}{ LPHB } \\
\hline & & HB- $15 \%$ CP & $18 \% \mathrm{CP}$ & $15 \% \mathrm{CP}$ \\
\hline Dry matter, \% & 90.47 & 90.77 & 90.52 & 91.13 \\
\hline Gross energy, $\mathrm{MJ} / \mathrm{kg}$ & 17.29 & 17.60 & 17.53 & 17.80 \\
\hline Crude protein, $\%$ & 17.91 & 14.03 & 17.66 & 14.72 \\
\hline Total phosphorus, $\%$ & 0.43 & 0.39 & 0.34 & 0.28 \\
\hline Phytate phosphorus ${ }^{2}, \%$ & 0.20 & 0.16 & 0.11 & 0.05 \\
\hline Available phosphorus ${ }^{3}, \%$ & 0.23 & 0.23 & 0.23 & 0.23 \\
\hline \multicolumn{5}{|l|}{ Essential amino acids, $\%$} \\
\hline arginine & 1.21 & 0.84 & 1.09 & 0.78 \\
\hline histidine & 0.49 & 0.35 & 0.44 & 0.34 \\
\hline isoleucine & 0.78 & 0.57 & 0.71 & 0.52 \\
\hline leucine & 1.37 & 1.02 & 1.27 & 0.98 \\
\hline lysine & 1.04 & 0.97 & 0.97 & 0.98 \\
\hline methionine & 0.32 & 0.30 & 0.32 & 0.31 \\
\hline phenylalanine & 0.97 & 0.74 & 0.94 & 0.75 \\
\hline threonine & 0.77 & 0.68 & 0.72 & 0.67 \\
\hline valine & 0.93 & 0.73 & 0.88 & 0.70 \\
\hline total & 7.88 & 6.20 & 7.34 & 6.03 \\
\hline \multicolumn{5}{|c|}{ Non-essential amino acids, \% } \\
\hline alanine & 0.80 & 0.60 & 0.75 & 0.58 \\
\hline aspartic acid & 1.73 & 1.11 & 1.46 & 0.96 \\
\hline cystine & 0.35 & 0.29 & 0.34 & 0.30 \\
\hline glutamic acid & 3.96 & 3.19 & 3.91 & 3.28 \\
\hline glycine & 0.78 & 0.58 & 0.73 & 0.56 \\
\hline serine & 0.91 & 0.65 & 0.81 & 0.60 \\
\hline proline & 1.45 & 1.30 & 1.56 & 1.41 \\
\hline total & 9.98 & 7.72 & 9.56 & 7.69 \\
\hline \multicolumn{5}{|c|}{ Apparent ileal amino acid supply $4 \%$} \\
\hline lysine & 0.83 & 0.83 & 0.83 & 0.83 \\
\hline methionine + cystine & 0.52 & 0.48 & 0.51 & 0.46 \\
\hline threonine & 0.47 & 0.47 & 0.47 & 0.47 \\
\hline tryptophan & 0.17 & 0.17 & 0.18 & 0.18 \\
\hline
\end{tabular}

${ }^{1}$ refer to Table 1

${ }^{2}$ calculated by using analysed phytate $\mathrm{P}$ content of barleys and $\mathrm{P}$ values (content and availability) of soyabean meal $(47.5 \% \mathrm{CP})$ from NRC (1998)

${ }^{3}$ total phosphorus minus phytate phosphorus

${ }^{4}$ apparent ileal digestible amino acid contents were calculated based on NRC (1998) values

The pigs remained healthy and usually consumed their meal allowances within 30 min after feeding throughout the experiment. The average BW of the pigs were $20.4 \pm 0.9,25.9 \pm 1.7,32.7 \pm 0.9$, and $39.9 \pm 1.3 \mathrm{~kg}$ at the beginning of periods 1 , 
2,3 , and 4 , respectively. The average BW of the pigs was $48.1 \pm 1.3 \mathrm{~kg}$ at the end of the experiment.

There were no differences in the ATTD of DM $(\mathrm{P}>0.05)$ and OM $(\mathrm{P}>0.05)$ among the diets (results not shown). The ATTD of DM ranged from 91.5 to $92.1 \%$. The ATTD of OM ranged from 93.0 to $93.5 \%$.

The $\mathrm{P}$ balance results are presented in Table 3 . The excretion of $\mathrm{P}$ in faeces was lower $(\mathrm{P}<0.001)$ and the ATTD and retention higher $(\mathrm{P}<0.001)$ in pigs fed the LPHB compared to the HB diets. The amount retained was lower $(\mathrm{P}<0.001)$ in pigs fed the LPHB diets. The excretion of $\mathrm{P}$ in faeces was lower $(\mathrm{P}<0.001)$ in pigs fed the 15 compared to the $18 \% \mathrm{CP}$ diets. The excretion of $\mathrm{P}$ in urine was higher $(\mathrm{P}=0.045)$ in pigs fed the 15 compared to the $18 \% \mathrm{CP}$ diets. The ATTD $(\mathrm{P}=0.271)$ and retention $(\mathrm{P}=0.309)$ of $\mathrm{P}$ were not different between pigs fed the 15 and $18 \% \mathrm{CP}$ diets. However, the amount of $\mathrm{P}$ retained was lower $(\mathrm{P}<0.001)$ in pigs fed the 15 compared to the $18 \% \mathrm{CP}$ diets. There were interactions between $\mathrm{CP}$ content and barley type for the amount absorbed $(\mathrm{P}=0.026)$ and retained $(\mathrm{P}=0.027)$. The amount retained was lower $(\mathrm{P}<0.001)$ in pigs fed the 15 compared to the $18 \%$ CP LPHB diets.

Table 3. Phosphorus balance in growing pigs fed the experimental diets

\begin{tabular}{|c|c|c|c|c|c|c|c|c|}
\hline \multirow{3}{*}{ Items } & \multicolumn{5}{|c|}{ Diets $^{1}$} & \multirow{2}{*}{\multicolumn{3}{|c|}{ Contrasts $^{2}$}} \\
\hline & \multirow{2}{*}{\multicolumn{2}{|c|}{$\begin{array}{c}\mathrm{HB} \\
18 \% \mathrm{CP} \quad 15 \% \mathrm{CP}\end{array}$}} & \multicolumn{2}{|c|}{ LPHB } & \multirow{2}{*}{ SEM } & & & \\
\hline & & & $18 \% \mathrm{CP}$ & $15 \% \mathrm{CP}$ & & $\mathrm{C}_{1}$ & $\mathrm{C}_{2}$ & $\mathrm{C}_{3}$ \\
\hline Intake $\mathrm{P}, \mathrm{g} / \mathrm{d}$ & 4.24 & 3.90 & 3.32 & 2.83 & - & - & - & - \\
\hline Faecal P, g/d & 1.84 & 1.59 & 1.22 & 1.03 & 0.047 & $<0.001$ & $<0.001$ & 0.572 \\
\hline Urinary $\mathrm{P}, \mathrm{mg} / \mathrm{d}$ & 8.2 & 10.4 & 8.0 & 10.1 & 0.001 & 0.045 & 0.820 & 0.978 \\
\hline Absorbed P, g/d & 2.40 & 2.31 & 2.10 & 1.80 & 0.045 & $<0.001$ & $<0.001$ & 0.026 \\
\hline Total excreted $\mathrm{P}, \mathrm{g} / \mathrm{d}$ & 1.85 & 1.60 & 1.23 & 1.04 & 0.047 & $<0.001$ & $<0.001$ & 0.574 \\
\hline Digestibility of $\mathrm{P}, \%$ & 56.2 & 58.8 & 63.0 & 63.2 & 1.188 & 0.271 & $<0.001$ & 0.331 \\
\hline Retention of $\mathrm{P}, \%$ & 56.0 & 58.5 & 62.8 & 62.8 & 1.193 & 0.309 & $<0.001$ & 0.320 \\
\hline Retained P, g/d & 2.39 & 2.30 & 2.09 & 1.79 & 0.455 & $<0.001$ & $<0.001$ & 0.027 \\
\hline
\end{tabular}

${ }^{1}$ refer to Table 1

${ }^{2} \mathrm{P}$-values of orthogonal contrasts: $\mathrm{C}_{1}=18 \% \mathrm{CP}$ vs $15 \% \mathrm{CP}$ diets, $\mathrm{C}_{2}=$ normal vs low-phytate diets, $\mathrm{C}_{3}=\mathrm{CP}$ level $\times$ barley type

The $\mathrm{N}$ balance results are presented in Table 4. The excretion of $\mathrm{N}$ in faeces $(\mathrm{P}=0.039)$ and urine $(\mathrm{P}<0.001)$ were higher in pigs fed the 18 compared to the $15 \% \mathrm{CP}$ diets. The ATTD of $\mathrm{N}$ was higher $(\mathrm{P}<0.001)$ as well as the amount retained $(\mathrm{P}=0.004)$ in pigs fed the 18 compared to the $15 \% \mathrm{CP}$ diets. The $\mathrm{N}$ excretion in faeces was lower $(\mathrm{P}=0.012)$ in pigs fed the LPHB compared to the HB diets, but the $\mathrm{N}$ excretion in urine was higher $(\mathrm{P}=0.001)$. There were no differences in the retention $(\mathrm{P}=0.499)$ and the amount of $\mathrm{N}$ retained $(\mathrm{P}=0.161)$ between pigs fed the HB and LPHB diets. The $\mathrm{N}: \mathrm{P}$ ratio was higher $(\mathrm{P}=0.002)$ in pigs fed the 18 compared to the $15 \% \mathrm{CP}$ diets and in pigs fed the LPBH $(\mathrm{P}<0.001)$ compared to the HB diets. 
Table 4. Nitrogen balance in growing pigs fed the experimental diets

\begin{tabular}{|c|c|c|c|c|c|c|c|c|}
\hline \multirow{3}{*}{ Items } & \multicolumn{5}{|c|}{ Diets $^{1}$} & \multirow{2}{*}{\multicolumn{3}{|c|}{ Contrasts $^{2}$}} \\
\hline & \multirow{2}{*}{\multicolumn{2}{|c|}{$\frac{\mathrm{HB}}{18 \% \text { CP } 15 \% \text { CP }}$}} & \multirow{2}{*}{\multicolumn{2}{|c|}{$\frac{\text { LPHB }}{18 \% \text { CP } 15 \% \text { CP }}$}} & \multirow[t]{2}{*}{ SEM } & & & \\
\hline & & & & & & $\mathrm{C}_{1}$ & $\mathrm{C}_{2}$ & $\mathrm{C}_{3}$ \\
\hline Intake $\mathrm{N}, \mathrm{g} / \mathrm{d}$ & 26.51 & 22.24 & 27.92 & 23.42 & - & - & - & - \\
\hline Faecal N, g/d & 3.62 & 3.27 & 3.21 & 3.14 & 0.098 & 0.039 & 0.012 & 0.177 \\
\hline Urinary $\mathrm{N}, \mathrm{g} / \mathrm{d}$ & 9.09 & 6.16 & 10.52 & 7.01 & 0.312 & $<0.001$ & 0.001 & 0.366 \\
\hline Absorbed N, g/d & 22.89 & 18.98 & 24.71 & 20.29 & 0.155 & $<0.001$ & $<0.001$ & 0.120 \\
\hline Total excreted N, g/d & 12.71 & 9.42 & 13.73 & 10.15 & 0.330 & $<0.001$ & 0.015 & 0.652 \\
\hline Digestibility of N, \% & 86.2 & 84.9 & 88.4 & 86.4 & 0.425 & $<0.001$ & $<0.001$ & 0.438 \\
\hline Retention of N, \% & 52.1 & 57.8 & 51.3 & 57.0 & 1.114 & $<0.001$ & 0.499 & 0.999 \\
\hline Retained N, g/d & 13.81 & 12.82 & 14.19 & 13.28 & 0.290 & 0.004 & 0.161 & 0.897 \\
\hline Excreta N:P ratio, g/g & 6.86 & 5.86 & 11.13 & 9.69 & 0.340 & 0.002 & $<0.001$ & 0.512 \\
\hline
\end{tabular}

\section{DISCUSSION}

The ATTD and retention of $\mathrm{P}$ were higher for pigs fed the LPHB compared to the HB diets (Table 3). The LPHB diets contained less SBM than the HB diets (Table 1) and the availability of P in SBM is lower than in barley (Cromwell, 2003). Thacker et al. $(2003,2004)$ also reported that the ATTD of P in finishing pigs fed a LPHB diet was higher than in pigs fed a HB diet. Although the ATTD and retention of $\mathrm{P}$ were higher, the amount of $\mathrm{P}$ retained was lower for pigs fed the LPHB than the HB diets. These results are in agreement with those reported by Veum et al. (2002) in studies with pigs fed hulled and low-phytate hulled barley. It should be mentioned, as reported in many studies (e.g., Veum et al., 2002; Liao et al., 2006), that the excretion of $P$ in urine is of a very small magnitude. Therefore, the total excretion values for $\mathrm{P}$ correspond closely to the excretion values in faeces.

The substitution of HB with LPHB decreased $(\mathrm{P}<0.001)$ the total $\mathrm{P}$ excretion by 33.5 and $35 \%$ for the 18 and $15 \%$ CP diets, respectively (Table 3 ). These results are in agreement with previous studies that evaluated low-phytate maize (Spencer et al., 2000; Veum et al., 2001; Bohlke et al., 2005), SBM (Sands et al., 2003) and barley (Li et al., 2001a,b; Veum et al., 2002) in poultry and swine diets. It should be mentioned that the pigs had restricted access to feed in the present study.

There were no differences in the ATTD and retention of $\mathrm{P}$ between the 18 and $15 \% \mathrm{CP}$ diets, but the amount of P retained was lower for pigs fed the $15 \% \mathrm{CP}$ diets (Table 3). The $15 \% \mathrm{CP}$ diets contained less SBM (Table 1) and the availability of $\mathrm{P}$ in SBM is lower than in barley (Cromwell, 2003). Lowering the CP content of the $18 \% \mathrm{CP}$ HB diet to $15 \% \mathrm{CP}$ decreased the total $\mathrm{P}$ excretion by $13.6 \%$. Lowering 
the $18 \%$ LPHB diet to $15 \%$ CP decreased the total P excretion by $15.4 \%$. The least amount of $\mathrm{P}$ for all diets was excreted by pigs fed the $15 \%$ CP LPHB diet.

The ATTD of N was lower in the 15 compared to the $18 \%$ CP diets (Table 4). The lower ATTD may be a direct result of changes in the ratios of ingredients. The content of SBM was lower in the 15 than $18 \%$ CP diets, and the content of barley higher. The ATTD of CP in SBM is higher than in barley (CVB, 1994).

In agreement with other studies (Zervas and Zijlstra, 2002b; Otto et al., 2003) the retention of $\mathrm{N}$ increased as the dietary $\mathrm{CP}$ content was decreased which was mainly due to a decrease in urinary $\mathrm{N}$ excretion (Table 4). The urinary $\mathrm{N}$ excretion decreased by $32 \%$ when the $\mathrm{CP}$ content was reduced from 18 to $15 \%$ in the diets containing HB; by $33 \%$ when the CP content was decreased for the LPHBcontaining diets. These results are in agreement with studies by Otto et al. (2003) and Shriver et al. (2003) who reported an approximately 50\% decrease in urinary $\mathrm{N}$ excretion of pigs fed low-CP diets supplemented with amino acids. Reducing the $\mathrm{CP}$ content from 18 to $15 \%$ decreased $(\mathrm{P}<0.001)$ the total $\mathrm{N}$ excretion by $26 \%$ for both the HB and LPHB diets.

Reducing the dietary CP content from 18 to $15 \%$ while supplementing with limiting AA decreased the daily amount of $\mathrm{N}$ retained by $7 \%$ for both $\mathrm{HB}$ and LPHB diets (Table 4). These results are in agreement with those reported by Zervas and Zijlstra (2000a) and Shriver et al. (2003). Zervas and Zijlstra (2002b) observed a $12 \%$ reduction in the retention of $\mathrm{N}$ in $30 \mathrm{~kg}$ pigs offered restricted access to a $15.6 \% \mathrm{CP}$ diet compared with that in pigs fed an $18.5 \% \mathrm{CP}$ diet, but the retention decreased only by $7 \%$ when pigs were offered unlimited access to these diets. Kerr and Easter (1995) reported that pigs fed a 12\% CP diet supplemented with lysine, tryptophan, and threonine retained less $\mathrm{N}$ than pigs fed a $16 \% \mathrm{CP}$ diet. The further addition of dispensable AA to the $12 \%$ CP diet increased the amount of $\mathrm{N}$ retained. Shriver et al. (2003) also reported that reducing the dietary $\mathrm{CP}$ content from 18 to $15 \%$ with appropriate AA supplementation in $36 \mathrm{~kg}$ pigs, offered unlimited access to feed, decreased the amount of $\mathrm{N}$ retained by $15 \%$ but growth performance was not affected.

In the present study, the diets were formulated to meet the NRC (1998) recommendations for apparent ileal digestible AA for growing pigs. However, due to the restricted feeding design, the daily intake of total lysine, methionine plus cystine, and threonine (g/d) of pigs fed the 15 and $18 \%$ CP diets were only 61, 66 and $65 \%$, and 63,73 and $72 \%$ of NRC (1998) recommended intake, respectively. The reduction in the amount of $\mathrm{N}$ retained may be attributed to inadequate daily intake of one or more indispensable AA, different digestible AA levels, AA imbalances (Kerr and Easter, 1995), or different efficiencies of AA utilization among diets (Zervas and Zijlstra, 2000a). Otto et al. (2003) suggested that endogenous N losses contribute to a substantial proportion of total $\mathrm{N}$ losses, as this contribution 
increases as the dietary $\mathrm{CP}$ concentration decreases. Therefore, an increased level of endogenous $\mathrm{N}$ losses may also lead to a reduction in the amount of $\mathrm{N}$ retained with low CP diets.

Reducing the $\mathrm{CP}$ content of the diet with AA supplementation will decrease $\mathrm{N}$ excretion (e.g., Kerr and Easter, 1995; Shriver et al., 2003). Kerr and Easter (1995) reported that for every 1 percentage unit decrease in CP content there was a $10 \%$ reduction in total $\mathrm{N}$ excretion. Shriver et al. (2003) reported a reduction of $8 \%$ in total $\mathrm{N}$ excretion for every 1 percentage unit decrease in $\mathrm{CP}$ content. In the present studies, there was a 7\% reduction in total $\mathrm{N}$ excretion for every 1 percentage unit decrease in dietary $\mathrm{CP}$ content.

The ATTD of $\mathrm{N}$ was higher in pigs fed the LPHB compared to the HB diets (Table 4). In vitro studies have shown that phytate may form insoluble complexes with proteins (Cheryan, 1980) and inhibit proteolytic enzymes (Singh and Krikorian, 1987). In theory, it is possible that a reduction in dietary phytate content will reduce the formation of insoluble complexes with proteins and the inhibitory effect of phytate on the proteolytic enzymes contributing to an improvement in protein (N) digestibility. However, there were no differences in the retention of $\mathrm{N}$ and the amount retained between pigs fed the HB and LPBH diets.

The N:P ratio in excreta of pigs fed the LPHB diets, regardless of dietary CP content, was higher in excreta of pigs fed the HB diets (Table 4). Spencer et al. (2000) also reported that feeding a low-phytate maize-SBM diet increased the N:P ratio in excreta, becoming more environmentally friendly, and more suitable to use as fertilizer.

In conclusion, the excretion of $\mathrm{P}$ can be greatly reduced by substitution of $\mathrm{HB}$ by LPHB in diets for growing pigs. The excretion of $\mathrm{N}$ was considerably reduced when the $18 \%$ CP diet was replaced by a $15 \%$ CP diet supplemented with AA, and there was a further reduction in $\mathrm{P}$ excretion. However, the reduction in $\mathrm{N}$ excretion was compromised by a decrease in the amount of $\mathrm{N}$ retained.

\section{ACKNOWLEDGEMENTS}

The authors thank K. Sauer and J. Hairong for technical assistance.

\section{REFERENCES}

AOAC, 2000. Official Methods of Analysis, Association of Official Analytical Chemists. 17 $7^{\text {th }}$ Edition. Arlington, VA

Bohlke R.A., Thaler R.C., Stein H.H., 2005. Calcium, phosphorus, and amino acid digestibility in low-phytate corn, normal corn, and soybean meal by growing pigs. J. Anim. Sci. 83, 23962403 
CCAC, Canadian Council on Animal Care, 1993. Guide to the Care and Use of Experimental Animals. Vol. 1. Ottawa, ON (Canada)

Cheryan M., 1980. Phytic acid interactions in food systems. CRC Crit. Rev. Food Sci. Nutr. 13, 297-335

Cromwell G.L., 2003. Update on phytase utilization in swine. Proceedings of Roche Pre-Conference Symposium, Eastern Canadian Nutrition Conference, Quebec City. Hoffmann-LaRoche Ltd., Cambridge, Ontario, pp. 29-45

CVB, 1994. Data about Chemical Composition, Digestibility and Feeding Values of Feedstuffs. Veevoedertabel, Centraal Veevoederbureau, Lelystad (The Netherlands)

FAO, Food and Agriculture Organization of the United Nations, 2002. Food Outlook. No. 1. Rome. Available: ftp://ftp.fao.org/docrep/fao/005/y6175e/y6175e00.pdf

Fenton T.W., Fenton M., 1979. An improved procedure for the determination of chromic oxide in feed and feces. Can. J. Anim. Sci. 59, 631-634

Haug W., Lantzsch H.J., 1983. Sensitive method for the rapid determination of phytate in cereals and cereal products. J. Sci. Food Agr. 34, 1423-1426

Huang G.S., Sauer W.C., He J.M., Hwangbo J., Wang X., 2003. The nutritive value of hulled and hulless barley for growing pigs. 1. Determination of energy and protein digestibility with the in vivo and in vitro method. J. Anim. Feed Sci. 12, 759-769

Jongbloed A.W., Lenis N.P., 1998. Environmental concerns of animal manure. J. Anim. Sci. 76, 2641-2648

Kaufmann C., Sauer W.C., Cervantes M., Zhang Y., He J., Htoo J.K., 2005. Amino acid and energy digestibility in different sources of rice bran for growing pigs. Can. J. Anim. Sci. 85, 355-363

Kerr B.J., Easter R.A., 1995. Effect of feeding reduced protein, amino acid-supplemented diets on nitrogen and energy balance in grower pigs. J. Anim Sci. 73, 3000-3008

Li Y.C., Ledoux D.R., Veum T.L., Raboy V., Zyla K., 2001a. Low phytic acid barley improves performance, bone mineralization, and phosphorus retention in turkey poults. J. Appl. Poultry Res. 10, 178-185

Li Y.C., Ledoux D.R., Veum T.L., Raboy V., Zyla K., Wikiera A., 2001b. Bioavailability of phosphorus in low phytic acid barley. J. Appl. Poultry Res. 10, 86-91

Liao S.F., Sauer W.C., Kies A.K., Cervantes M., Htoo J.K., He J.M., 2006. Effect of phytase supplementation to diets for weanling pigs on the utilization of phosphorus and calcium. Interciencia 31, 262-267

Nelson T.S., 1967. The utilization of phytate phosphorus by poultry. A review. Poultry Sci. 46, 862-869

NRC, 1998. Nutrient Requirements of Swine. 10 $0^{\text {th }}$ Edition. National Academy Press. Washington, DC

Otto E.R., Yokoyama M., Ku P.K., Ames N.K., Trottier N.L., 2003. Nitrogen balance and ileal amino acid digestibility in growing pigs fed diets reduced in protein concentration. J. Anim. Sci. $81,1743-1753$

Ravindran V., Bryden W.L., Kornegay E.T., 1995. Phytates: occurrence, bioavailability and implications in poultry nutrition. Poultry Avian Biol. Rev. 6 (2), 125-143

Sands J.S., Ragland D., Wilcox J.R., Adeola O., 2003. Relative bioavailability of phosphorus in lowphytate soybean meal for broiler chicks. Can. J. Anim. Sci. 83, 95-100

SAS, 1988. SAS/STAT User's Guide: Statistics. Release 6.03. SAS Institute, Inc. Cary, NC

Shriver J.A.S., Carter D., Sutton A.L., Richert B.T., Senne B.W., Pettey L.A., 2003. Effects of adding fiber sources to reduced-crude protein, amino acid-supplemented diets on nitrogen excretion, growth performance, and carcass traits of finishing pigs. J. Anim. Sci. 81, 492-502

Singh M., Krikorian A.D., 1982. Inhibition of trypsin activity in vitro by phytase. J. Agr. Food Chem. 30, 799-800 
Spencer J.D., Allee G.L., Sauber T.E., 2000. Phosphorus bioavailability and digestibility of normal and genetically modified low-phytate corn for pigs. J. Anim. Sci. 78, 675-681

Sutton A.L., Kephardt K.B., Verstegen M.W.A., Canh T.T., Hobbs P.J., 1999. Potential for reduction of odorous compounds in swine manure through diet modification. J. Anim. Sci. 77, 430-439

Thacker P.A., Rossnagel B.G., Raboy V., 2003. Phosphorus digestibility in low phytate barley fed to finishing pigs. Can. J. Anim. Sci. 83, 101-104

Thacker P.A., Rossnagel B.G., Raboy V., 2004. Effect of phytase supplementation on phosphorus digestibility in low-phytate barley fed to finishing pigs. Arch. Anim. Nutr. 58, 61-68

Veum T.L., Ledoux D.R., Bollinger D.W., Raboy V., Cook A., 2002. Low-phytic acid barley improves calcium and phosphorus utilization and growth performance in growing pigs. J. Anim. Sci. 80, 2663-2670

Veum T.L., Ledoux D.R., Raboy V., Ertl D.S., 2001. Low-phytic acid corn improves nutrient utilization for growing pigs. J. Anim. Sci. 79, 2873-2880

Zervas S., Zijlstra R.T., 2002a. Effects of dietary protein and fermentable fiber on nitrogen excretion patterns and plasma urea in grower pigs. J. Anim. Sci. 80, 3247-3256

Zervas S., Zijlstra R.T., 2000b. Effects of dietary protein and oathull fiber on nitrogen excretion patterns and postprandial plasma urea profiles in grower pigs. J. Anim. Sci. 80, 3238-3246 